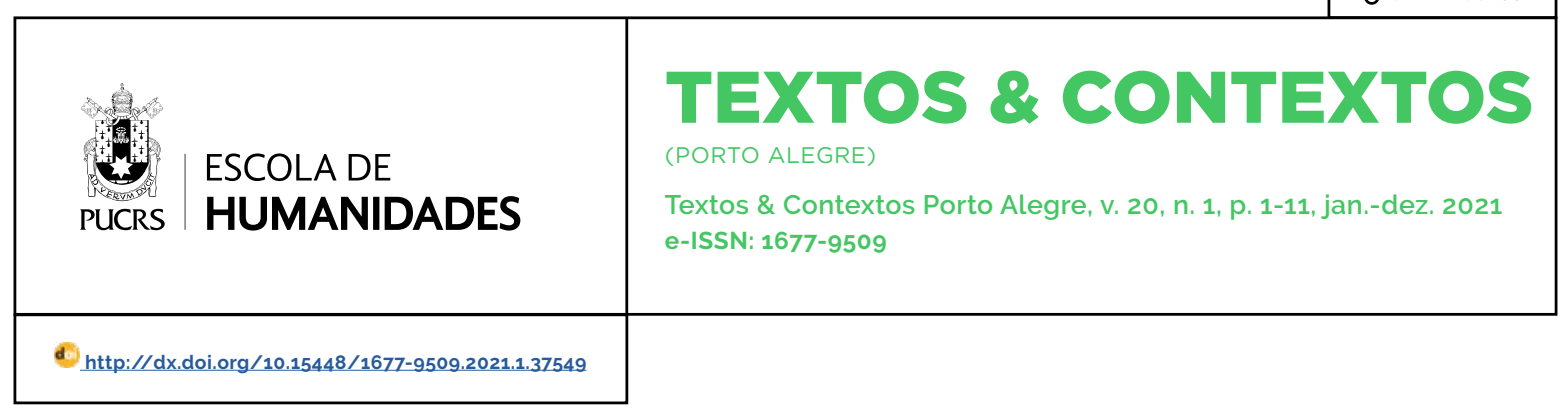

ARTIGO

\title{
O giro de 180 graus e as dificuldades processuais do acesso à Justiça do Trabalho
}

The 180 degree turn and the process difficulties of access to Labor Justice

\author{
Nivea Maria Santos \\ Souto Maior ${ }^{1}$ \\ orcid.org/0000-0003-4561-8819 \\ legaliteadv@yahoo.com.br
}

Recebido em: 2 abr. 2020.

Aprovado em: 15 dez. 2020.

Publicado em: 06 maio. 2021.

\section{(c) (i)}

Artigo está licenciado sob forma de uma licença Creative Commons Atribuição 4.0 Internacional.
Resumo: Este artigo propõe uma reflexão critica acerca das consequências processuais promovidas pela reforma trabalhista brasileira no tocante ao acesso à Justiça do Trabalho e à gestão dos conflitos laborais. Para tanto, analisa-se a origem dessa Justiça especializada e a sua evolução histórica, cuja tendência era de ampliação de suas competências. Tal estudo adotou, como orientação metodológica, o materialismo crítico-dialético, através da pesquisa documental e bibliográfica. Por último, foram listadas as principais inovações processuais determinadas pela reforma trabalhista que dificultaram o acesso do trabalhador ao Poder Judiciário, promovendo consequentemente um esvaziamento em seu campo jurisdicional. Palavras-chave: Acesso à Justiça. Solução de conflitos. Reforma trabalhista.

Abstract: This paper aims at a critical reflection on the procedural consequences made by the Brazilian Labor Reform regarding access to Labor Justice and the management of labor conflicts. First, we analyze the origin of this specialized justice and its historical evolution, whose tendency was to expand its competences. This study adopted, as methodological guidance, Marx's critical-dialectical materialism, through documentary and bibliographic research. Finally, we will list the main procedural innovations determined by the Labor Reform that made it difficult for workers to gain access to justice, thereby promoting an emptying of their jurisdictional field. Keywords: Access to Justice. Conflict management. Labor reform.

\section{Introdução}

Recentemente, houve a apresentação de uma Proposta de Emenda à Constituição (PEC), na qual se propunha a unificação da Justiça do Trabalho à Justiça Federal o que, via de consequência, provocaria a extinção dessa Justiça especializada² (MARTINES, 2019). As razões de tal proposta legislativa seriam supostamente os elevados custos da Justiça do Trabalho e a possibilidade de sua extinção levaria a uma racionalização na prestação jurisdicional, argumentando-se também que a existência desse ramo provocaria um cenário de encorajamento à judicialização e à extrema litigiosidade.

São justamente os falaciosos motivos acima mencionados que causam paulatinamente um esvaziamento na atuação da Justiça do Trabalho, em razão de as antigas taxas de congestionamento dos processos trabalhistas estarem em decréscimo vertiginoso após a vigência da Lei n. ${ }^{\circ}$ 13.467/2017, que altera a Consolidação das Leis do Trabalho (CLT); tem-se,

Universidade Estadual da Paraiba (UEPB), Campina Grande, PB, Brasil.

A PEC foi apresentada pelo deputado federal Paulo Eduardo Martins (PSC-PR), porém, em outubro de 2019, o parlamentar desistiu da proposta diante da grande repercussão negativa. 
assim, como questão de pesquisa a investigação de quais seriam os novos obstáculos processuais de acesso à Justiça do Trabalho.

Nesse sentido, o presente estudo - materializado através de uma pesquisa bibliográfica e documental com enfoque nas legislações pertinentes ao tema - objetiva esboçar o cenário conflituoso de dificuldades processuais do acesso à Justiça do Trabalho, com ênfase na reviravolta ocasionada pela reforma trabalhista.

De início, será feito um panorama histórico de criação e evolução da Justiça do Trabalho, abrangendo sua emergência enquanto mero órgão de natureza administrativa, sua transição do Poder Executivo para o Poder Judiciário, e o seu apogeu após a Emenda Constitucional n. ${ }^{\circ}$ 45/2004, que ampliou significativamente a sua competência. À luz do passado, será possivel considerar a Justiça do Trabalho como instrumento de luta social conquistado pela classe trabalhadora. Além disso, a sua permanência nos quadros do Judiciário concretiza o acesso à Justiça, que é o mais fundamental de todos os direitos, por ser a forma de reivindicação dos demais direitos.

Em continuidade, apresenta-se o atual processo de desjudicialização das relações de trabalho, sendo que o atual estado da arte descreve e avalia as principais mudanças de acesso à Justiça após a reforma trabalhista, como, por exemplo, a restrição da gratuidade e a instituição de honorários sucumbenciais, entre outras medidas. Desse modo, a dificuldade na judicialização dos direitos trabalhistas insere-se na lógica capitalista, tornando as garantias sociais cada vez mais mínimas.

Com isso, o objetivo central deste texto, referenciado no materialismo histórico-dialético, é o de ratificar o avanço do conservadorismo através das recentes legislações contrarreformistas, mais especificamente um estudo analítico da Lei Federal n. ${ }^{\circ}$ 13.467/2017 em comparação com as normas que a antecederam, em um contexto involutivo das leis trabalhistas para recrudescimento de obstáculos ao acesso à Justiça.
Por fim, atenta-se que a figura de linguagem adotada no título é justificada em virtude de o giro de 180 graus representar um ângulo raso (formado por meia-volta), equivalendo em uma metonímia ao cenário totalmente oposto ao inicial. Ou seja, se antes havia um suposto excesso de judicialização dos conflitos trabalhistas, a contemporaneidade demonstra diametralmente o contrário: o esvaziamento da atuação da Justiça do Trabalho com o decrescente número de processos ajuizados nesse ramo do Poder Judiciário em virtude dos entraves impostos pela reforma.

\section{Ensaio histórico do acesso à Justiça do Trabalho}

Antes de submergir direto no ponto principal deste trabalho, são necessárias algumas noções sobre o acesso à justiça em sentido amplo, para posteriormente - em recorte teórico -analisar o acesso à jurisdição estatal em seu aspecto histórico e o estreitamento dessa via até então bastante eleita pelos trabalhadores. O acesso à Justiça deve ser priorizado como norma-matriz dos demais direitos, uma vez que serve de condicionante para o exercício dos demais direitos fundamentais. Emerge do ideal de Estado Social, como a construção de uma sociedade livre, justa e solidária, redutora das desigualdades sociais e regionais, e provedora do bem de todos.

Com isso, o acesso à Justiça trata-se abstratamente de um dos Direitos Humanos, ${ }^{3}$ caracterizados por ser inato ao homem independentemente de qualquer outra condição, sendo uma garantia essencial à construção de sua dignidade enquanto pessoa: "Artigo 8. Todo ser humano tem direito a receber dos tribunais nacionais competentes remédio efetivo para os atos que violem os direitos fundamentais que lhe sejam reconhecidos pela constituição ou pela lei" (ONU, 1948).

Todavia, o marco teórico acima mencionado não guarda pertinência com o cenário brasileiro, pois tal visão eurocêntrica destoa do nosso país,

\footnotetext{
3 A propósito, no ano de 1979, o jurista tcheco-francês Karel Vasak empregou, pela primeira vez, o termo "gerações aos direitos do homem" com a intenção de categorizar os direitos humanos conforme as dimensões inspiradas na revolução francesa (liberdade, igualdade e fraternidade); por esse ângulo, o direito de acesso à Justiça se localiza na segunda dimensão, em virtude da necessidade de o Estado agir de modo proativa no acesso à justiça de maneira integral e ao final associada ao ideal de igualdade em sentido material (PIOVESAN, 2019).
} 
que não criou uma formação cultural adequada de movimentos emancipacionistas. E para além desse ideário jusnaturalista, o sociólogo português Boaventura de Sousa Santos alcunhou o acesso efetivo à Justiça como um: "[...] direito charneira, um direito cuja denegação acarretaria a de todos os demais. Uma vez destituidos de mecanismos que fizessem impor o seu respeito, os novos direitos sociais e económicos passariam a meras declarações políticas, de conteúdo e função mistificadores" (SANTOS, 1999, p. 146).

A obra paradigmática sobre o tema foi escrita por Cappelletti e Garth (1988). Tratava-se de uma coletânea inédita de estudos que buscavam soluções práticas para a efetividade do acesso à justiça em diversos paises, que podem ser sintetizadas em três ondas renovatórias: ${ }^{4}$ a primeira onda, assistência judiciária para os pobres a fim de garantir a acessibilidade a todos, independentemente da condição econômica do jurisdicionado; segunda onda, representação jurídica para os interesses transindividuais, em uma concepção mais social e coletiva; terceira onda, enfoque de celeridade e de novos mecanismos de acesso à Justiça.

Logo, o acesso à Justiça possui vários sentidos, sua polissemia é direcionada desde a noção básica da possibilidade de qualquer pessoa de ter seu litígio apreciado pelo Estado (denominada como primazia da inafastabilidade e preconizada no inciso XXXV do artigo $5^{\circ}$ da CF/88); como também se refere à garantia fundamental de direitos, haja vista a ideia de que a efetivação plena de um direito se inicia com a garantia de acesso ao Poder Judiciário. Por fim, tem-se como sinônimo de acesso ao direito no sentido do deslocamento da proteção estatal para a participação do próprio jurisdicionado na solução de seus conflitos.

Esta última acepção é sensivel a uma "[...] perspectiva moderna do acesso à justiça não se limitar ao acesso ao judiciário, mas a uma série de mecanismos socialmente aceitos, capazes de promover continuamente a pacificação social" (MAILLART; SANTOS; GONCALVES, 2019, p.
222), pois seria impossivel imaginar que apenas a lei/jurisdição fosse o único método capaz de resolver os conflitos. No cenário internacional, as primeiras tentativas de resolução de conflitos relacionados às relações de trabalho estão nos Conseils de Proud' Hommes (conselhos de homens prudentes) ocorrido na época napoleônica no ano de 1806. O êxito alcançado por esse conselho instigou outros países europeus a seguir o modelo francês, desvinculado do Poder Judiciário, com o objetivo de apreciar causas trabalhistas principalmente através da conciliação.

Em território nacional, a conciliação foi um mecanismo que atuou na gênese da Justiça do Trabalho no Brasil, como forma de inserção no processo de expansão do capitalismo mundial, em virtude da obtenção do consenso (em termos gramscianos) da classe trabalhadora ao projeto político capitalista.

\begin{abstract}
A conciliação foi historicamente usada para solucionar divergências entre as elites políticas e econômicas e para alijar a participação da população em geral nos processos decisórios. Serviu para encobrir a violência contra os movimentos de resistência das populações originárias no momento da ocupação do território brasileiro e, posteriormente, dos negros e dos abolicionistas, no longo periodo escravocrata. Na mesma direção, o recurso à conciliação foi essencial para assegurar os interesses hegemônicos nos periodos de acirramento das lutas entre capital e trabalho. quando da consolidação da sociedade de classes (HILLESHEIM, 2015, p. 55).
\end{abstract}

Assim, a Justiça do Trabalho surgiu da necessidade de criação de instituições públicas para deslocamento da questão social, tratada, até então, como questão de polícia, em benefício da burguesia industrial e para acomodação da classe operária.

No Brasil, o embrião da Justiça do Trabalho deu-se com o Decreto n. ${ }^{\circ}$ 16.027/1923, que criou o Conselho Nacional do Trabalho (CNT), instituido no âmbito do Ministério da Agricultura, Indústria e Comércio, que somente resolvia dissidios individuais laborais de forma indireta, em virtude de ser encarregado de planejar e de fiscalizar a implantação

\footnotetext{
4 Em harmonia com as ondas renovatórias de acesso à justiça, no Brasil houve a edição de Pactos Republicanos (os dois primeiros eventos ocorreram nos anos de 2004 e 2009), cujo projeto trata da parceria dos Três Poderes da República (Supremo Tribunal Federal, Palácio do Planalto e Congresso Nacional) para traçar estratégias em busca de um sistema de Justiça mais acessivel e efetiva (BRASIL, 2010)
} 
de uma legislação social no Brasil. Posteriormente, as Juntas de Conciliação e Julgamento foram criadas no ano de 1932, órgãos também de natureza administrativa compostos pelos juizes classistas, representantes dos empregados e dos empresários, e por juizes presidentes, indicados pelo Governo.

A denominação propriamente dita "Justiça do Trabalho" surgiu na Constituição Federal de 1934. e ainda era mantida no âmbito administrativo. Após pouco mais de uma década, por força do Decreto-Lei n. ${ }^{\circ}$ 9.797/1946 é que a Justiça do Trabalho veio a integrar o Poder Judiciário. Frisa-se que antes mesmo de haver a previsão constitucional do princípio da inafastabilidade da jurisdição, a Justiça do Trabalho já existia em formato rudimentar no Poder Executivo.

Desde 1999, quando foram extintos os juizes classistas, as Juntas de Conciliação e Julgamento são chamadas de Varas do Trabalho. A partir de então, a Justiça do Trabalho no Brasil tem as seguintes instâncias hierárquicas, nesta ordem: Varas do Trabalho, Tribunal Regional do Trabalho e Tribunal Superior do Trabalho, sendo sua função gerenciar conflitos da relação entre capital e trabalho.

Logo, não cogitar, naquele periodo republicano, um projeto de criação da Justiça do Trabalho implicaria inevitavelmente em meios de autodefesa e da justiça pelo uso da força, afinal a classe trabalhadora carecia de um mecanismo legal para recorrer em favor de suas reivindicações.

A parcela mais inteligente e mais esclarecida dos detentores do poder, dos meios de produção, dotada de visão reformista, logo percebeu que a melhor forma de assegurar o ritmo e rendimento da produção e o bom funcionamento da empresa era estabelecer um código de deveres e disciplina, com mutuas obrigações, no qual a autoridade patronal só fosse suscetivel de discussão ou contestação perante um órgão institucionalmente autorizado, distante do recinto do estabelecimento patronal, em que o limite de concessões fosse o respeito à hierarquia e a soberania econômica do empregador. Para tal órgão seriam canalizados os desentendimentos e as reclamações, os dissidios com os trabalhadores. E, assim, o julgamento dos conflitos seria feito por agentes do Estado, entes estranhos - aparentemente ou não - neutros (BOMFIM, 2011, p. 178-179).

Mais recentemente, com o advento da Emenda Constitucional n. ${ }^{\circ}$ 45/2004, houve a alteração na redação do artigo 114 da Constituição Federal, oportunidade em que os termos "conciliar e julgar" foram substituidos por "processar e julgar". Mas essa mudança não desnaturou o princípio da conciliação, havendo, além disso, uma ampliação significativa na sua competência em virtude da inclusão das ações que discutem as relações de trabalho (gênero), e não apenas as relações de emprego (espécie).

Dessa feita, ressalta-se em apertada síntese que a Justiça do Trabalho surgiu inicialmente como uma forma alternativa de composição da lide. A sua primeira intenção era a de resolver os conflitos trabalhistas de maneira consensual, para atendimento de uma necessidade do Estado e em favor da produção e disciplina nos estabelecimentos empresariais; provavelmente o que se deseja nos tempos atuais é resgatar o status quo ante dessa Jurisdição.

\section{As principais mudanças "pós-reforma" do acesso à Justiça do Trabalho}

As atuais tendências neoliberais de racionalização da força do trabalho requisitaram novos patamares de regulamentação da Justiça do Trabalho, como parte do projeto burguês de reestruturação laboral (ALVES, 2017), concretizado no governo de Michel Temer (2016-2018) pela Lei n. ${ }^{\circ}$ 13.467/2017. E como ressalta Supiot (2016, p. 247), "o Direito do Trabalho apresenta a vantagem de ser um ramo do Direito que, tendo ligação à legalidade "burguesa", é ao mesmo tempo um dos alvos privilegiados dos teóricos da desregulamentação".

o compromisso de realizar reformas (inclusive a trabalhista), com a adequação do Poder Judiciário aos interesses do mercado econômico, foi uma das condições para concessão de empréstimos internacionais, conforme documento técnico n. ${ }^{\circ}$ 319/1996 emitido pelo Banco Mundial aos países da América Latina (DAKOLIAS, 1996, p. 16).

A Justiça do Trabalho sofre as determinações desse poder global que é o mercado. Este comando está acima da eficácia reguladora dos Estados Nacionais, não importando quais sejam as caracteristicas histórico-sociais desse ou daquele pais (TAVARES, 2004, p. 71). 
Em outras palavras, a obstaculização do acesso à Justiça significa a redução do campo político-institucional em favor da classe trabalhadora.

E em descompasso com a promoção integral de acesso à Justiça, particularmente à jurisdição trabalhista, ao exigir do Estado não apenas a normatização de as suas demandas, mas também a criação de meios eficazes para a sua concreção, a reforma trabalhista - cuja vigência iniciou-se em 11 de novembro de 2017 - promoveu uma série de impasses processuais ao acesso dos trabalhadores ao Poder Judiciário.

No panorama das transformações das relações de trabalho e do direito do trabalho, os sistemas de resolução de conflitos e de acesso à justiça do trabalho são objeto de mutações importantes. A partir da crise de 2008 são induzidas reformas na jurisdição do trabalho, em especial naqueles paises em que está organizada uma Justiça especializada do Trabalho. O sentido dessas reformas na jurisdição é duplo: criar obstáculos ao acesso à justiça, e neutralizar o controle judicial por juizes e tribunais do trabalho (MACHADO, 2019, p. 256, grifo nosso).

Conforme o relatório Justiça em Números, realizado pelo Conselho Nacional de Justiça (CNJ), os processos trabalhistas estavam se multiplicando no Brasil, tornando o acesso à Justiça mais moroso para a grande maioria da classe operária, porém, nos últimos dois anos, houve uma reviravolta nos dados.

Prestando-se a realizar a um comparativo estatístico na Justiça do Trabalho, o CNJ constatou que, no ano de 2016, existiam 3.668 juizes do Trabalho na primeira instância para gerenciar um volume de 5.394.420 processos pendentes, uma média de $56 \%$ de taxa de congestionamento (CNJ, 2017). Diferente cenário de litigiosidade ocorreu em 2018: o número de magistrados praticamente permaneceu igual (3.599 juizes), porém a quantidade de ações pendentes baixou para 4.861.352 processos com consequente queda na taxa de congestionamento para 45\% (CNJ, 2019).

Esse cenário de desjudicialização ocorreu em todo o país, fato corroborado ao se verificar o número de ajuizamentos das demandas perante a Justiça do Trabalho após um ano de vigência da Reforma Trabalhista; mais precisamente, uma redução de $36 \%$ na quantidade de processos, conforme dados do Tribunal Superior do Trabalho (BRASIL, 2018b). ${ }^{5}$ A limitação no acesso à Justiça do Trabalho gerada pela reforma representa um verdadeiro backlash, ${ }^{6}$ por ter como objetivo o afastamento da Justiça no caso concreto (microjustiça).

Em âmbito estadual, os índices da TRT da Paraíba (13 ${ }^{\text {a }}$ Região) são mais alarmantes: ${ }^{7}$ estima-se que em novembro de 2017, mês no qual entrou em vigência a reforma trabalhista, existiam 19.831 processos pendentes de baixa nas Varas do Trabalho desse Tribunal; decorrido quase um biênio da reforma trabalhista, constavam em setembro de 2019 apenas 9.297 processos pendentes de baixa, o que representa uma queda vertiginosa de quase metade da taxa de congestionamento.

Dito isso, o Brasil está no ranking mundial de países em que mais se sonegam os direitos trabalhistas no mundo. Se havia antes um excesso de litigiosidade, era em razão do descumprimento contumaz dos direitos trabalhistas. ${ }^{8}$ Os direitos trabalhistas não deixaram de ser sonegados, o que aconteceu foi a criação de uma lei que trouxe uma série de empecilhos ao acesso a essa jurisdição especializada. Somadas às dificuldades processuais abaixo analisadas, há também um clima de medo dos autores/reclamantes em ajuizar um processo trabalhista e ao término ter que arcar com uma divida financeira, caso a outra parte vença a lide.

\subsection{Dos honorários sucumbenciais}

Após mais de sete décadas de criação da Justiça do Trabalho, rompe-se o paradigma da

\footnotetext{
5 Outrossim, dados de cinco tribunais regionais consultados apontam uma queda de cerca de $60 \%$ no número de processos ajuizados em relação à média do primeiro semestre de 2017 (ANAMATRA, 2017).

6 "O backlash é uma reação adversa não desejada à atuação judicial. Para ser mais preciso, é, literalmente, um contra-ataque politico ao resultado de uma deliberação judicial. Tal contra-ataque manifesta-se por meio de determinadas formas de retaliação, que podem ocorrer em várias 'frentes': a revisão legislativa de decisões controversas; [...]" (MARMELSTEIN, 2016, p. 3).

7 Relatórios de produção disponiveis em: https://www.trt13.jus.br/institucional/corregedoria/producao-dos-magistrados/10-grau.

8 O relatório Justiça em números do CNJ divulgou que, em 2018, o assunto mais demandado na Justiça do Trabalho procedeu da ausência de pagamentos de verbas rescisórias não custeadas pelos empregadores (CNJ, 2019), ou seja, mesmo após a reforma trabalhista, permanece a cultura reiterada de inadimplemento das obrigações mais basilares na relação empregatícia.
} 
inexistência de sucumbência e essa espécie de honorários passa a ser devida, no percentual de $5 \%$ a $15 \%$ sobre o valor de liquidação da sentença, sobre o proveito econômico obtido ou sobre o valor atualizado da causa, a teor do artigo 791A da Consolidação das Leis Trabalhistas (CLT). "Antes a lei trabalhista não aceitava os honorários sucumbenciais em virtude do jus postulandi que, antes, vigorava como regra, e agora vigora como exceção. Com o advento do Processo Judicial Eletrônico (PJe), a contratação de advogado é quase indispensável, dai a necessidade da mudança da regra" (CASSAR; BORGES, 2017, p. 99).

Um dos motivos ensejadores dessa novidade legislativa estaria no argumento de que na Justiça do Trabalho haveria um estímulo à litigiosidade, em uma espécie de "cassino gratuito" - termo utilizado em uma sentença proferida no TRT da

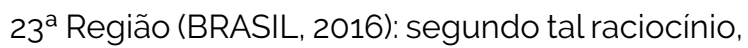
podia-se jogar de graça, sem a necessidade de se pagar, mesmo em caso de derrota, ou seja, trata-se de uma analogia com o ajuizamento temerário de ações pelo reclamante.

Existem alguns fatores a serem sopesados, a exemplo do percentual ser menor em comparação àquele estipulado no $\$ 2^{\circ}$ do artigo 85 do CPC, cujos honorários podem ser arbitrados em até 20\% sobre o valor das causas que tramitam na Justiça Comum. Tal minoração aparenta inicialmente ser tratamento discriminatório com os advogados que atuam na Justiça do Trabalho, não havendo justificativa razoável para a diferenciação desses percentuais.

Outro item é a excessiva onerosidade em impor a cobrança de honorários sucumbenciais mesmo para aqueles autores que obtiveram a concessão da assistência judiciária gratuita, conforme nova redação da CLT, in verbis:

Artigo 791-A [...] $\S 4^{\circ}$ Vencido o beneficiário da justiça gratuita, desde que não tenha obtido em juizo, ainda que em outro processo, créditos capazes de suportar a despesa, as obrigações decorrentes de sua sucumbência ficarão sob condição suspensiva de exigibilidade e somente poderão ser executadas se, nos dois anos subsequentes ao trânsito em julgado da decisão que as certificou, o credor demonstrar que deixou de existir a situação de insuficiência de recursos que justificou a concessão de gratuidade, extinguindo-se, passado esse prazo, tais obrigações do beneficiário. (BRASIL, [2017]).
Atente-se também que o TRT do Rio Grande do Sul proferiu a inconstitucionalidade do artigo acima transcrito por considerar a norma violadora da garantia de acesso à Justiça, em razão de impor "[...] ao trabalhador beneficiário do instituto da assistência judiciária gratuita limitação ao exercício do amplo direito de ação e aos efeitos da concessão da justiça gratuita de forma integral" (BRASIL, [2018a]).

Não somente em sede dos Tribunais Regionais do Trabalho (TRT), mas também perante o Supremo Tribunal Federal o viés reformista apresentado pela Lei n. $13.467 / 2017$ tornou-se objeto de inúmeras Ações Diretas de Inconstitucionalidade (ADI), sob o fundamento de que, ao modificar substancialmente o texto da CLT, reverberou-se um conjunto de supressões de direitos fundamentais sociais garantidos pela Constituição Federal, de tal forma que "[...] tropeços foram evidenciados e revelaram um frontal e injustificável descompasso entre a atividade legislativa e os principios constitucionais" (BARCELLOS; BARROSO, 2018, p. 298).

Nesse interim, a possibilidade de concessão de honorários sucumbenciais nos processos trabalhistas é atualmente objeto de uma Ação de Inconstitucionalidade (ADI n. ${ }^{\circ} 5766$, de autoria do procurador-geral da República) perante o Supremo Tribunal Federal (STF), com relatoria do ministro Luís Roberto Barroso e pendente de deliberação final. Cabe destacar os dizeres dos dois votos já proferidos em sentidos diferentes, nos quais, entretanto, existe uma tendência em não considerar inconstitucional esse ponto da reforma trabalhista:

[...] Após o voto do Ministro Roberto Barroso (Relator), julgando parcialmente procedente a ação direta de inconstitucionalidade, para assentar interpretação conforme a Constituição, consubstanciada nas seguintes teses: "1. O direito à gratuidade de justiça pode ser regulado de forma a desincentivar a litigância abusiva, inclusive por meio da cobrança de custas e de honorários a seus beneficiários. 2. A cobrança de honorários sucumbenciais do hipossuficiente poderá incidir: (i) sobre verbas não alimentares, a exemplo de indenizações por danos morais, em sua integralidade; e (ii) sobre o percentual de até 30\% do valor que exceder ao teto do Regime Geral de Previdência Social, mesmo quando pertinente a verbas remuneratórias. 3. É legítima a cobrança de custas judiciais, em razão da ausência do reclamante à audiência, mediante prévia intimação pessoal 
para que tenha a oportunidade de justificar o não comparecimento, e após o voto do Ministro Edson Fachin, julgando integralmente procedente a ação, pediu vista antecipada dos autos o Ministro Luiz Fux. Ausentes o Ministro Dias Toffoli, neste julgamento, e o Ministro Celso de Mello, justificadamente. Presidência da Ministra Carmen Lúcia. Plenário, 10.5.2018. Aguarda julgamento final (BRASIL, 2019, grifo nosso).

E diferente da tendência esposada no Brasil, o Reino Unido já declarou inconstitucionais os dispositivos que oneram excessivamente o acesso do trabalhador ao Poder Judiciário:

A partir de um diálogo com reformas análogas efetivadas anteriormente à brasileira, importante ressalvar que os dispositivos da reforma do Reino Unido que restringiam o acesso ao Judiciário foram declarados inconstitucionais pela Suprema Corte em julho de 2017, no julgamento de recurso proposto por UNISON, Sindicato dos Servidores Públicos do Reino Unido. É que no Employment Tribunals and the Employment Appeal Tribunal Fees Order 2013, o governo britânico, buscando reduzir a litigiosidade e visando a dissuadir a propositura de demandas e a estimular acordos prévios, fixou taxas para acesso aos tribunais trabalhistas. Tanto no Reino Unido quanto no Brasil, as taxações reduziram as demandas de forma substantiva (BIAVASCHI; TEIXEIRA, 2019, p. 40 , grifo nosso).

No Brasil, se antes da Reforma Trabalhista havia uma presunção quase absoluta da condição de miserabilidade daquele trabalhador que ajuizasse um processo, haja vista a concessão praticamente automática da assistência judiciária gratuita em razão da situação de desemprego da maioria dos demandantes, na atualidade pouco importa se o trabalhador obtenha ou não créditos na ação trabalhista, a exigibilidade da cobrança dos honorários sucumbenciais perdurará ao longo de dois anos.

Destarte, exige-se, a partir de então, uma maior cautela das partes ao buscarem acessar a Justiça do Trabalho. Assim o custo financeiro do processo advindo pela possivel condenação de honorários advocatícios sucumbenciais repercute no embaraço da judicialização de legítimos direitos sociais dos trabalhadores.

\subsection{Dos honorários periciais}

A regra anterior era a de que a prova pericial de responsabilidade do beneficiário da justiça gratuita seria custeada com recursos alocados no orçamento da União. Melhor explicando, a União assumia integralmente os custos da prestação dos serviços periciais diante da incapacidade financeira do beneficiário. Pela nova regra, ${ }^{9}$ a parte sucumbente no objeto da perícia será responsável pelo pagamento dos honorários periciais, ainda que beneficiária da justiça gratuita, a teor do artigo 790-B da CLT.

A única exceção à nova regra será a hipótese de a parte vencida não obter proveito econômico da ação trabalhista, caso em que a União garantirá o pagamento dos honorários periciais, ou seja, subsiste ao erário a responsabilidade subsidiária pelos honorários periciais. O Projeto de Lei n. ${ }^{\circ}$ 6.787/2016, que deu origem à reforma trabalhista, fundamentou tal mudança legislativa no fato de haver um abuso postulatório de pedidos dessa natureza:

[...] a União custeia, a título de honorários periciais, valores entre dez a vinte milhões de reais por ano, para cada um dos vinte e quatro Tribunais Regionais do Trabalho, somente em relação a demandas julgadas improcedentes, ou seja, demandas em que se pleiteou o que não era devido" (BRASIL, 2016, p. 68).

De fato, era inquestionável a banalização do direito de ação que envolvia provas periciais na Justiça do Trabalho, sendo crivel a opção normativa adotada para coibir excessos processuais. Existiam outras soluções menos onerosas ao trabalhador, como, por exemplo, "[...] a formação de corpo próprio de peritos fixos, preferencialmente concursados, ou a formação de espaços próprios para a realização das perícias" (SILVA, 2017, p. 138).

Nesse sentido, comprometem-se os pedidos que tenham objeto relacionado com o meio ambiente de trabalho - verbi gratia, adicional de insalubridade ou indenização por acidente

9 Inclusive, esse novo regramento diverge de entendimento sumular do TST: "Súmula n. ${ }^{\circ} 457$ do TST. HONORÁRIOS PERICIAIS. BENEFICIÁRIO DA JUSTIÇA GRATUITA. RESPONSABILIDADE DA UNIÃO PELO PAGAMENTO. RESOLUÇÃO N. ${ }^{\circ}$ 66/2010 DO CSJT. OBSERVÂNCIA. A União é responsável pelo pagamento dos honorários de perito quando a parte sucumbente no objeto da perícia for beneficiária da assistência judiciária gratuita, observado o procedimento disposto nos artigos $1^{\circ}, 2^{\circ}$ e $5^{\circ}$ da Resolução n. ${ }^{\circ} 66 / 2010$ do Conselho Superior da Justiça do Trabalho - CSJT" (BRASIL, [2014]). 
de trabalho - e corre-se o risco de haver maior descumprimento das regulamentações sobre saúde e segurança do trabalhador, ante o desestímulo de ajuizamento de processos trabalhistas com essa temática.

Ademais, o Código de Processo Civil, ao disciplinar a gratuidade da Justiça às partes, elencou pormenorizadamente o que estaria incluido. Entre outros itens, estipulou em seu artigo 98 no inciso VI: "[...] os honorários do advogado e do perito e a remuneração do intérprete ou do tradutor nomeado para apresentação de versão em português de documento redigido em língua estrangeira" (BRASIL, [2015], grifo nosso).

Diante do conflito aparente das normas, como seria possivel compatibilizar o códex processual com o texto celetista? A legislação vigente na Justiça Comum é muito mais benéfica do que a própria lei que regula os atos processuais da Justiça do Trabalho.

\begin{abstract}
Muitos diriam, para tentar encontrar uma explicação ao texto legal, que o perito poderia ser parcial, pois, ao saber que não receberia o seu pagamento, no caso de improcedência da pretensão autoral objeto da perícia, tenderia em favor do autor. Outros poderiam falar que o espírito ético e o profissionalismo do perito não deveriam se deixar contaminar, pois este há de ser imparcial, como, inclusive, estabelece a lei, sendo mesmo caso de seu afastamento a sua parcialidade. Ademais, continuariam, trata-se de risco do negócio, pois também há casos em que o advogado do autor nada recebe, para tanto, basta que o seu cliente (o reclamante) não se sagre vitorioso! Não importa qual corrente prevaleça, o fato é que o legislador subverteu toda a edificação conceitual e a tradição sobre a gratuidade de justiça. Mas, enfim, como disse acima, tudo não passa de uma política legislativa que, não raro, se apresenta nefasta aos interesses daquele que deveria receber a sua proteção (CASSAR; BORGES, 2017, p. 150, grifo nosso).
\end{abstract}

Essa nova racionalidade sobre a judicialização dos conflitos trabalhistas exige uma reorientação para além do ordenamento jurídico. Se o problema for de cunho político, a solução também deve ser de igual grandeza, pois as barreiras processuais de acesso à Justiça do Trabalho acima avaliadas promovem o esvaziamento do sentido democrático da Constituição Federal de 1988.

\subsection{Arquivamento por ausência injustificada do autor}

Antes da reforma trabalhista, a parte reclamante que não comparecesse em audiência não sofreria nenhuma penalidade, sendo o processo apenas arquivado (extinto sem julgamento do mérito) e se abriria em seguida a possibilidade de o autor ajuizar novamente o processo sem nenhum ônus. Pela nova lei, o reclamante passa a arcar com as custas processuais em caso de arquivamento por ausência injustificada à audiência, mesmo se beneficiário da Justiça gratuita, conforme artigo 844, $\$ 2^{\circ}$ da CLT.

Esse dispositivo torna o pagamento das custas do primeiro processo como pressuposto para distribuição de nova/segunda ação trabalhista, isto é, transfigurou-se a isenção das custas processuais em caráter indenizatório ou punitivo (SILVA, 2017).

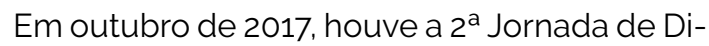
reito Material e Processual do Trabalho. ${ }^{10}$ Naquela ocasião, foram aprovados diversos enunciados, cabendo destaque ao tema acesso à justiça:

Enunciado $n^{\circ}$ 103. Acesso à justiça. artigo 844 . $\S 2^{\circ}$ e $\S 3^{\circ}$, da CLT. Inconstitucionalidade. Viola o principio de acesso à justiça a exigência de cobrança de custas de processo arquivado como pressuposto de novo ajuizamento. o princípio do acesso à justiça é uma das razões da própria existência da justiça do trabalho, o que impede a aplicação dessas regras, inclusive sob pena de esvaziar o conceito de gratuidade da justiça (ANAMATRA, [2017]).

A ideia do legislador seria a de inibir o gasto em vão da máquina judiciária e também da parte ré que movimenta custo e tempo para realização da audiência e elaboração da defesa, respectivamente. À primeira vista, a mens legislatoris manifesta-se razoável, todavia, o ponto nodal é a inexistência de definição de quais seriam os motivos legalmente justificáveis para desoneração das custas processuais, ficando o trabalhador à margem da discricionariedade do juiz em puni-lo ou não. 
Isso porque, ao se trabalhar com a ideia punitiva, ou seja, de que as custas passam a integrar o rol de uma espécie de punição ao trabalhador hipossuficiente, pelo simples fato de ter movimentado a máquina judiciária, também se viola o acesso à justiça. Ora, se o trabalhador movimentou a máquina judiciária apenas para tentar "ganhar um qualquer" (como se diz por ai), agiu de má-fé e por tal conduta deve ser apenado. Mas daí condená-lo ao pagamento de custas! Ademais, não há como saber, no momento da propositura da ação, qual será o resultado desta (CASSAR; BORGES, 2017, p. 149).

Com isso, o risco processual extremamente alto e caro de se litigar perante a Justiça do Trabalho conflita com o texto constitucional, que literalmente adjetiva a concessão da assistência jurídica gratuita de forma "integral" àqueles economicamente vulneráveis (BRASIL, 1988, artigo $5^{\circ}$, inciso LXXIV).

Destarte, as balizas que criaram o Direito Processual do Trabalho estão desaparecendo. Essa mudança de eixo é deletéria ao sistema de proteção social ao trabalhador porque reorienta de forma abusiva o regime de custas e despesas processuais, via de consequência em desfavor da garantia fundamental do acesso à Justiça.

\section{Considerações finais}

Prima facie, não existe nenhum problema em adotar reformas legislativas. A intenção literal da palavra assinala o desejo de melhoramento e readaptação aos novos influxos sociais, situação tão presente na sociedade brasileira. O fato é que a expressão utilizada não condiz com o seu conteúdo. A reforma trabalhista, em seu aspecto processual, prestou um desserviço ao acesso à Justiça do Trabalho, não somente dificultando o ajuizamento de novos processos, como também estimulando a inadimplência de dividas trabalhistas.

Desse modo, a Lei n. ${ }^{\circ}$ 13.467/2017 é antiprocessual, haja vista a novidade legislativa - na maior parte de seu texto - dificultar o acesso à jurisdição. Os dados estatísticos de antes e depois da Reforma são contundentes e a tendência de esvaziamento da antiga taxa de congestionamento pode implicar na extinção dessa modalidade de justiça especializada.

A extinção da Justiça do Trabalho não significa que deixarão de existir as lides sociais de capital versus trabalho, muito menos a diminuição de fraudes trabalhistas. E em tempos que o óbvio precisa ser dito, a permanência da Justiça do Trabalho nos quadros do Poder Judiciário não é importante apenas para o trabalhador, mas também para as empresas com compromisso social que buscam evitar o dumping social enquanto fator de concorrência desleal no mercado econômico.

Portanto, o conceito contemporâneo de acesso à justiça nos conflitos trabalhistas sofreu um atraso no ponto de vista jurisdicional e, em contrapartida, outros canais de acesso, como a arbitragem e a conciliação extrajudicial, foram favorecidos, a caminho de uma lógica segundo a qual uma via de solução estimula o desacesso aos outros.

\section{Referências}

ALVES, Giovanni. Reforma trabalhista, modernização catastrófica e miséria da república brasileira. In: RAMOS, Gustavo Teixeira et al. (org.). 0 golpe de 2016 e a reforma trabalhista: narrativas de resistência. Bauru: Canal 6, 2017. p. 138-145.

ASSOCIAÇÃO NACIONAL DOS MAGISTRADOS DA JUSTIÇA DO TRABALHO (ANAMATRA). Enunciados

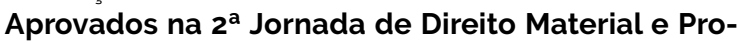
cessual do Trabalho, realizada de 9 a 10 de outubro de 2017 em Brasilia (DF). Disponivel em: http://Www. jornadanacional.com.br/listagem-enunciados-aprovados-vis1.asp. Acesso em: 2 dez. 2019.

BARCELLOS, Ana Paula de; BARROSO, Luis Roberto. Os valores sociais do trabalho. In: CANOTILHO, J. J. Gomes; MENDES, Gilmar Ferreira; SARLET, Ingo Wolfgang; STRECK, Lênio Luiz. (coord.). Comentários à Constituição do Brasil. 2. ed. São Paulo: Saraiva Jur, 2018. p. 294-301.

BIAVASCHI, Magda Barros; TEIXEIRA, Marilane Oliveira. Balanço da reforma trabalhista em perspectiva econômica, as falácias dos argumentos de seus defensores e os impactos nas instituicõos públicas do trabalho. Revista Juridica Trabalho e Desenvolvimento Humano, Campinas, v. 2, n. 1, p. 19-55, jul. 2019.

BOMFIM, Benedito Calheiros. Gênese do direito do trabalho e a criação da justiça do trabalho no Brasil. Revista do Tribunal Superior do Trabalho, Brasilia, v. 77, n. 2, abr./jun. 2011.

BRASIL. Câmara dos Deputados. Parecer ao Projeto de Lei $n^{\circ} \mathbf{6 . 7 8 7}$ de 2016. Relator Deputado Rogério Marinho. Comissão especial destinada a proferir parecer ao Projeto de Lei $n^{\circ} 6.787$, de 2016, do poder executivo que "altera o Decreto-Lei $n^{\circ} 5452$, de $1^{\circ}$ de maio de 1943 - Consolidação das Leis do Trabalho, e a Lei no 6019, de 3 de janeiro de 1974, para dispor sobre eleições de representantes dos trabalhadores no local de trabalho e sobre o trabalho temporário, e dá outras providências. Brasília, 2016. Disponivel em: https://www. camara.leg.br/proposicoesWeb/prop mostrarintegra? codteor $=1548298$ \&filename $=$ SBT $+2+$ PL678716 $\%$ 253D\%253E+PL+6787/2016. Acesso em: 25 out. 2019. 
BRASIL. [Constituição (1934)]. Constituição da República dos Estados Unidos do Brasil de 1934. Rio de Janeiro: Presidência da República, 1934. Disponivel em: http://Www.planalto.gov.br/ccivil_03/constituicao/ constituicao34.htm. Acesso em: 5 jan. 2021.

BRASIL. [Constituição (1988)]. Constituição da República Federativa do Brasil de 1988. Brasília, DF: Presidência da República, 1988. Disponivel em: http://wwww.planalto. gov.br/ccivil_03/constituicao/constituicaocompilado. htm. Acesso em: 5 jan. 2021.

BRASIL. Decreto n. ${ }^{\circ} \mathbf{1 6 . 0 2 7}$, de $\mathbf{3 0}$ de abril de 1923 Crêa o Conselho Nacional do Trabalho. Rio de Janeiro: Presidência da República, 1923. Disponivel em: http:// www.planalto.gov.br/ccivil_03/decreto/1910-1929/ D16027.html. Acesso em: 5 jan. 2021.

BRASIL. Decreto-Lei . $^{\circ} \mathbf{5 . 4 5 2}$, de $\mathbf{1}^{\circ}$ de maio de 1943 Aprova a Consolidação das Leis do Trabalho (CLT). Rio de Janeiro, 1943. Disponível em: http:// wwww.planalto.gov.br/ ccivil_03/decreto-lei/del5452.htm. Acesso em: 25 out. 2019.

BRASIL. Decreto-Lei № 9.797 , de 9 de setembro de 1946. Altera disposições da Consolidação das Leis do Trabalho referentes à Justiça do Trabalho, e dá outras providências. Rio de Janeiro, 1946. Disponivel em: http:// www.planalto.gov.br/ccivil_03/decreto-lei/Del.9797. htm. Acesso em: 5 jan. 2021

BRASIL. [Constituição (1988)]. Emenda Constitucional n. ${ }^{\circ}$ 45, de 30 de dezembro de 2004 . Altera dispositivos dos arts. 5 $, 36,52,92,93,95,98,99,102,103,104,105$, 107, 109, 111, 112, 114, 115, 125, 126, 127, 128, 129, 134 e 168 da Constituição Federal, e acrescenta os arts. 103-A, 103B, 111-A e 130-A, e dá outras providências. Disponivel em: http://www.planalto.gov.br/ccivil_03/constituicao/ emendas/emc/emc45.htm. Acesso em: 5 jan. 2021.

BRASIL. Lei n. 13.467, de 13 de julho de 2017. Altera a Consolidação das Leis do Trabalho (CLT), aprovada pelo Decreto-Lei $n^{\circ} 5.452$, de $1^{\circ}$ de maio de 1943 , e as Leis $\mathrm{n}^{\circ}$ 6.019, de 3 de janeiro de 1974, 8.036, de 11 de maio de 1990, e 8.212, de 24 de julho de 1991, a fim de adequar a legislação às novas relações de trabalho. Brasília, DF: Presidência da República, 2017. Disponivel em: http://www.planalto.gov.br/ccivil_03/_ato20152018/2017/lei/l13467.htm. Acesso em: 25 out. 2019

BRASIL. Lei $n^{\circ} \mathbf{1 3 . 1 0 5}$, de 16 de março de 2015 . Código de Processo Civil. Brasília, DF: Presidência da República, 2015. Disponivel em: http://www.planalto. gov.br/ccivil_03/_ato2015-2018/2015/lei/l13105.htm. Acesso em: 25 out. 2019.

PACTO Republicano: parceria entre os Três Poderes contribui para a democracia. Notícias STF, Brasilia, 15 nov. 2010. Disponivel em: http://www.stf.jus.br/portal/cms/verNoticiaDetalhe asp?idConteudo $=165751$. Acesso em: 25 out. 2019

BRASIL. Supremo Tribunal Federal. Ação Direta de Inconstitucionalidade $n .{ }^{\circ}$ 5766/DF. Relator: ministro Luis Roberto Barroso. 7 mar. 2019. Disponivel em: http://portal.stf.jus.br/processos/detalhe.asp?incidente $=5250582$. Acesso em: 25 out. 2019.
BRASIL. Tribunal Regional do Trabalho da $13^{\text {a }}$ Região (PB). $1^{\circ}$ Grau: Relatórios de produção de Varas do Trabalho e Juizes, nas fases de Conhecimento e Execução (2015 a 2020). Disponivel em: https://www.trt13.jus.br/ institucional/corregedoria/producao-dos-magistrados/10-grau. Acesso em: 5 jan. 2021.

BRASIL. Tribunal Regional do Trabalho (23 ${ }^{a}$ Região) Processo n. 0000115-83.2016.5.23.0005. $5^{\text {a }}$ Vara do Trabalho de Cuiabá (MT); Juiza: Eleonora Alves Lacerda; Tipo do documento: Sentença; Autor: Edalice Ferreira de Souza; Réu: JCF Indústria e Comércio LTDA. Julgado Improcedente. Data do Julgamento: 8 jul. 2016. Dados da publicação: Diário da Justiça Eletrônico, p. 369, 11 jul. 2016

BRASIL. Tribunal Regional do Trabalho da $4^{\mathrm{a}}$ Região. Processo n. 0020024-05.2018.5.04.0124 - RO. Órgão Julgador: Tribunal Pleno; Desembargador Relator: Beatriz Renck; Tipo do documento: Acórdão (6ª Turma). Recorrente: Renato Rocha; Recorrido: Antonio Assis Berbigier Construções EPP. Resultado: Provimento parcial do Apelo. Data do julgamento: 27 nov. 2019. Dados da publicação: Diário da Justiça Eletrônico, p. 378, 3 dez. 2019.

CAPPELLETTI, Mauro; GARTH, Bryant. Acesso à Justiça Tradução: Ellen Gracie Northfleet. Porto Alegre: Sérgio Antonio Fabris Editor, 1998.

CASSAR, Vólia Bomfim; BORGES, Leonardo Dias. Comentários à reforma trabalhista. São Paulo: Método, 2017.

CONSELHO NACIONAL DE JUSTIÇA (CNJ). Justiça em Números 2017 (ano-base 2016). Brasilia: CNJ, 2017. Disponivel em: https://www.cnj.jus.br/pesquisas-judiciarias/justica-em-numeros/. Acesso em: 25 out. 2019.

CONSELHO NACIONAL DE JUSTIÇA (CNJ). Justiça em Números 2019 (ano-base 2018). Brasília: CNJ, 2019. Disponivel em: https://Www.cnj.jus.br/wp-content/ uploads/conteudo/arquivo/2019/08/justica_em_numeros20190919.pdf. Acesso em: 25 out. 2019.

DAKOLIAS, Maria. O Setor Judiciário na América Latina e Caribe: elementos para reforma. Washington: Banco Mundial, 1996.

HILLESHEIM, Jaime. Conciliação trabalhista: ofensiva sobre os direitos dos trabalhadores na periferia do capitalismo. 2015. Tese (Doutorado em Serviço Social) - Universidade Federal de Santa Catarina, Florianópolis, 2015

MACHADO, Sidnei. A judicialização do conflito do trabalho na reforma trabalhista brasileira de 2017. Revista Juridica Trabalho e Desenvolvimento Humano, Campinas, v. 2, n. 1, p. 255-271, jul. 2019.

MAILLART, Adriana Silva; SANTOS, Ricardo Soares Stersi dos; GONCALVES, Jessica. Access to justice and administration of legal conflicts: from the sentence culture to a consensual culture / Acesso à justiça e gestão de conflitos juridicos: da cultura da sentença para uma cultura do consenso. Revista de Direito Brasileira, Florianópolis, v. 22, p. 219-235, 2019.

MARMELSTEIN, George. Efeito Backlash da Jurisdição Constitucional: reações políticas ao ativismo judicial. Bolonha: 2016. Texto-base de palestra proferida durante o Terceiro Seminário Ítalo-Brasileiro. Disponivel em: https:// www.academia.edu/35675035/Efeito_Backlash_da_Jurisdição_Constitucinal. Acesso em: 25 nov. 2019. 
MARTINES, Fernando. Deputado apresenta PEC para acabar com a Justiça do Trabalho. Consultor Juridico. 9 out. 2019. Disponivel em: https://www.conjur.com. br/2019-out-og/deputado-apresenta-pec-acabar-justica-trabalho. Acesso em: 25 nov. 2019.

ORGANIZAÇÃO DAS NAÇÕES UNIDAS (ONU). Declaração Universal dos Direitos Humanos. Paris, 1948. Disponivel em: https://ead.stf.jus.br/cursos/controleconstitucionalidade/files/aula3/declaracao_universal_direitos_humanos.pdf. Acesso em: 25 nov. 2019.

PIOVESAN, Flávia. Direitos humanos e justiça internacional: um estudo comparativo dos sistemas regionais europeu, interamericano e africano. 9. ed. São Paulo: Saraiva Educação, 2019.

PRIMEIRO ano da reforma trabalhista: efeitos. Notícias do TST, Brasilia, 5 nov. 2018. Disponivel em: http://www. tst.jus.br/noticias/-/asset_publisher/8gDk/content/ primeiro-ano-da-reforma-trabalhista-efeitos. Acesso em: 5 jan. 2021.

SANTOS, Boaventura de Sousa. Pela mão de Alice: o social e o político na pós-modernidade. 7. ed. Porto: Afrontamento, 1999.

SILVA, Homero Batista Mateus da. Comentários à reforma trabalhista. São Paulo: Editora Revista dos Tribunais, 2017.

SUPIOT, Alain. Crítica do direito do trabalho. 3. ed. Lisboa: Fundação Calouste Gulbenkian, 2016.

TAVARES, Maria Augusta. Os fios (in)visiveis da produção capitalista: informalidade e precarização do trabalho. São Paulo: Cortez, 2004.

TOTAL de ações trabalhistas cai mais de $90 \%$. Anamatra na Midia, Brasília, 20 nov. 2017. Disponivel em: https:// www.anamatra.org.br/imprensa/anamatra-na-midia/ 25913-total-de-acoes-trabalhistas-cai-mais-de-9o. Acesso em: 2 jul. 2018.

\section{Nivea Maria Santos Souto Maior}

Mestra em Direito Público pela Universidade Estácio de Sá, no Rio de Janeiro, RJ, Brasil; mestra em Serviço Social pela Universidade Estadual da Paraiba (UEPB), em Campina Grande, PB, Brasil; especialista em Direito do Trabalho e Direito Processual do Trabalho pela Universidade Cândido Mendes, no Rio de Janeiro, RJ, Brasil; advogada.

\section{Endereço para correspondência}

Nivea Maria Santos Souto Maior

Vieira Souto Advogados Associados

Rua Otacilio Nepomuceno, 100-A, salas 09/12

Catolé, 58410-160

Campina Grande, PB, Brasil 